\title{
BMJ Open Sex differences in the risk profile of hypertension: a cross-sectional study
}

\author{
Saswata Ghosh, ${ }^{1,2}$ Simantini Mukhopadhyay, ${ }^{2}$ Anamitra Barik ${ }^{1,3}$
}

To cite: Ghosh S,

Mukhopadhyay S, Barik A. Sex differences in the risk profile of hypertension: a cross-sectional study. BMJ Open 2016;6:e010085. doi:10.1136/bmjopen-2015010085

- Prepublication history for this paper is available online. To view these files please visit the journal online (http://dx.doi.org/10.1136/ bmjopen-2015-010085).

Received 24 September 2015 Revised 28 May 2016 Accepted 8 July 2016

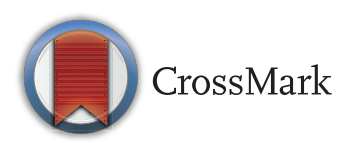

${ }^{1}$ Society for Health and Demographic Surveillance, Suri, West Bengal, India ${ }^{2}$ Institute of Development Studies Kolkata, Kolkata, West Bengal, India

${ }^{3}$ Niramay TB Sanatorium and Chest Clinic, District Hospital, Suri, Birbhum, West Bengal, India

Correspondence to Dr Anamitra Barik; anomitro2010@gmail.com

\section{ABSTRACT}

Objective: To assess the socioeconomic and behavioural risk factors associated with hypertension among a sample male and female population in India. Setting: Cross-sectional survey data from a Health and Demographic Surveillance System (HDSS) of rural West Bengal, India was used.

Participants: 27589 adult individuals (13 994 males and 13595 females), aged $\geq 18$ years, were included in the study.

\section{Primary and secondary outcome measures:}

Hypertension was defined as mean systolic blood pressure (SBP) $\geq 140 \mathrm{~mm} \mathrm{Hg}$ or diastolic blood pressure (DBP) $\geq 90 \mathrm{~mm} \mathrm{Hg}$, or if the subject was undergoing regular antihypertensive therapy. Prehypertension was defined as SBP $120-139 \mathrm{~mm} \mathrm{Hg}$ and DBP $80-89 \mathrm{~mm} \mathrm{Hg}$. Individuals were categorised as non-normotensives, which includes both the prehypertensives and hypertensives. Generalised ordered logit model (GOLM) was deployed to fulfil the study objective.

Results: Over $39 \%$ of the men and $25 \%$ of the women were prehypertensives. Almost $12.5 \%$ of the men and $11.3 \%$ of the women were diagnosed as hypertensives. Women were less likely to be nonnormotensive compared to males. Odds ratios estimated from GOLM indicate that women were less likely to be hypertensive or prehypertensive, and age (OR 1.04, 95\% Cl 1.03 to 1.05; and OR $1.08,95 \% \mathrm{Cl}$ 1.07 to 1.09 for males and females, respectively) and body mass index (OR $1.64,95 \% \mathrm{Cl} 1.38$ to 1.97 for males; and $\mathrm{OR} 1.32,95 \% \mathrm{Cl} 1.08$ to 1.60 for females) are associated with hypertension.

Conclusions: An elevated level of hypertension exists among a select group of the rural Indian population. Focusing on men, an intervention could be designed for lifestyle modification to curb the prevalence of hypertension.

\section{INTRODUCTION}

On 25 September 2015, India endorsed the Sustainable Development Goal for health to set a target to decrease premature deaths from non-communicable diseases (NCDs) by one-third by $2030 .{ }^{1}$ Globally, NCDs are estimated to be the leading cause of mortality. ${ }^{2}$ Among NCDs, hypertension (high blood pressure (BP) or arterial hypertension)

\section{Strengths and limitations of this study}

- Non-communicable diseases are an impending epidemic in developing countries. In light of this trend, the current study throws substantial light on the prevalence of hypertension in rural India which is poorly understood.

- The uniqueness and strength of the study lies in the study site as it is based on a demographic surveillance site and has a significantly large sample size.

- The study is based on cross-sectional data, which does not allow determination of causal relationships between hypertension and its risk factors.

- Information on the known risk factors of hypertension such as dietary intake, salt consumption, family history of hypertension, duration of diabetes, and physical activity were not available in the dataset. Also other unmeasured factors like genetic, social and sex-specific characteristics may have affected the results obtained in the present study.

affects one in four individuals globally, making it the single most important risk factor for mortality and the third highest cause of morbidity. ${ }^{3}$ With a population of over 1.25 billion people, hypertension in India is responsible for $57 \%$ of all stroke deaths and $24 \%$ of coronary heart disease deaths. ${ }^{4}$ According to the 2008 estimates of the $\mathrm{WHO}$, the prevalence of high $\mathrm{BP}$ among Indians is $21.1 \%$, with $21.3 \%$ among males and $21 \%$ among females. ${ }^{5}$ A systematic review on the prevalence of hypertension in India reported ranges of $13.9-46.3 \%$ and $4.5-58.8 \%$ in urban and rural areas of India, respectively. ${ }^{6}$

Coupled with the potential determinants of hypertension, sex differences in hypertension -which exist in human populations-are attributed to both biological and behavioural factors. The biological factors include sex hormones, chromosomal differences, and other biological sex differences that are protective against hypertension in women. ${ }^{7}$ These factors become prominent in adolescence and persist through adulthood until 
women reach menopause. ${ }^{8}$ Behavioural risk factors for hypertension include high body mass index (BMI), smoking, and low physical activity. Affluence is growing in rural India, thus raising the risky sociodemographic and lifestyle factors contributing to the burden of hypertension.

Most of the earlier studies conducted in India focused on the increasing burden of hypertension and associated cardiovascular disease and stroke in urbanised populations. ${ }^{9}$ A study conducted in a rural disadvantaged community in India revealed that in addition to traditional risk factors such as age and obesity, men from relatively socioeconomically advantaged groups are more prone to hypertension compared to women. ${ }^{9}$ This pattern was similar to a study in Vietnam ${ }^{10}$ but contrary to a study carried out in Indonesia in $2000 .^{11} \mathrm{~A}$ recent study among urban Chinese adults showed that the prevalence of prehypertension was greater in males than females. ${ }^{12}$ Although the prevalence of hypertension among the rural population was found to be the highest in eastern India, ${ }^{3}$ little research has been conducted in this region using large-scale survey data. To bridge this gap, the present study attempts to identify risk factors of hypertension among a selected male and female population, using data from a rural Health and Demographic Surveillance System (HDSS) site of West Bengal, India.

\section{METHODS}

\section{Data}

Data were used from the Birbhum HDSS, covering 351 villages in four administrative blocks in rural areas of the Birbhum district of West Bengal, India. The HDSS is a longitudinal cohort study, which was designed to study demographic changes, population health and epidemiology, and healthcare utilisation. A multi-stage sampling design was adopted to select sample households. ${ }^{13}$ First, administrative blocks were selected based on sociodemographic characteristics of the population. Then villages were selected from the administrative blocks according to probability proportional to size sampling, followed by households within villages by stratified sampling. Thus the sample households are self-weighted. Besides collecting data on vital statistics, antenatal and postnatal tracking, and conducting verbal autopsies, periodic surveys capturing sociodemographic and economic conditions were conducted twice. ${ }^{13}$ Causes of death data, according to International Classification of Diseases (ICD), from verbal autopsies collected for the years 2012 and 2013 showed that approximately $25 \%$ of the deaths were attributed to hypertensive heart diseases. ${ }^{13}$

The present study uses data from a combination of four surveys of the Birbhum HDSS, namely, a hypertension survey (measurement of $\mathrm{BP}$ of individuals aged $\geq 18$ years) in 2012, the second wave of socioeconomic survey (conducted in 2012-2013), a lifestyle survey (conducted in 2012), and a survey of physical or anthropometric measures (conducted in 2011-2012). Indicators of socioeconomic status and cultural characteristics were obtained from the socioeconomic survey, while data on tobacco usage and alcohol consumption were obtained from the lifestyle survey. Data obtained from these four separate surveys were matched through a unique identification number. Although BP was measured for 28455 individuals (14 414 males and 14041 females), analysis was restricted to 27589 individuals (13994 males and 13595 females) for whom complete information was available. Upon compilation of data used in the study, the consistency was checked rigorously.

\section{BP measurements: inclusion and exclusion criteria}

BP of each participant was measured using a digital sphygmomanometer (OMRON, Model- HEM-7111) after participants had been sitting quietly for at least $10 \mathrm{~min}$. Three consecutive measurements were taken 5 min apart on the right arm, with the person in a sitting position. The measurement was taken by the field surveyors (who were undergraduates with at least 3 years' experience of large scale survey data collection) after 2 days of training. The study included HDSS residents aged $\geq 18$ years, whose BP was measured at least twice. The exclusion criteria were: non-residents of HDSS; individuals $<18$ years of age; residents who were absent during the survey; persons with disability; and those whose $\mathrm{BP}$ was not measured twice. All values of BP measurements were checked and randomly cross-verified for consistency. Using international standards, ${ }^{14}$ a hypertensive condition was identified when the mean systolic blood pressure (SBP) was $\geq 140 \mathrm{~mm} \mathrm{Hg}$, the diastolic blood pressure (DBP) was $\geq 90 \mathrm{~mm} \mathrm{Hg}$, or if the respondent was undergoing regular antihypertensive therapy. Hypertension was divided into two stages of severity: stage 1 (SBP $140-159 \mathrm{~mm} \mathrm{Hg} / \mathrm{DBP} \quad 90$ $99 \mathrm{~mm} \mathrm{Hg}$ ); and stage 2 (SBP $\geq 160 \mathrm{~mm} \mathrm{Hg} / \mathrm{DBP} \geq 100$ DBP). Also, prehypertension was diagnosed when SBP was between 120-139 $\mathrm{mm} \mathrm{Hg}$ and DBP was between 80 $89 \mathrm{~mm} \mathrm{Hg}$. We have introduced a broad term called 'non-normotension' which includes both the prehypertensives and hypertensives, irrespective of the stage of hypertension.

\section{Predictor variables}

We have included the predictor variables guided by the studies conducted in India and developing countries. Predictor variables used in the analysis primarily fall into four categories: individual level (age, sex, and educational attainment); household level (religion, ethnicity, and economic status); substance use (tobacco usage and alcohol consumption); and BMI. Studies conducted in India have included BMI, family history of hypertension, smoking, and alcohol use as the risk factors of hypertension. ${ }^{15}{ }^{16}$ The proxy indicators for socioeconomic status, education, food habits, and occupation were included as predictor variables in studies conducted in similar settings. ${ }^{17}$ A study conducted in Vietnam (using data from a Vietnam HDSS site) used education, occupation, and 
economic conditions as the (only) indicators explaining the determinants of hypertension. ${ }^{18}$ However, to our knowledge, no single study conducted to date has used a comprehensive set of all possible variables affecting hypertension.

Monthly per capita household expenditure was first calculated from total monthly household expenditure and number of household members. This was then divided into five quintiles representing the richest, richer, middle, poorer and poorest, which act as a proxy for household economic status. Religion and ethnicity affiliation were pooled to form a single categorised variable as non-scheduled caste (SC)/scheduled tribe (ST) Hindu, Hindu SC, Hindu ST, and non-Hindu. BMI was calculated from the information on weight $(\mathrm{kg})$ and height $(\mathrm{m})$ of the respondents measured.

\section{Analytical model}

Bivariate and multivariate analyses were performed to attain the study objective. The $\chi^{2}$ test was used to identify the difference in proportion. To identify the determinants of hypertension status, generalised ordered logit models (GOLMs) were used. The primary outcome variable in the analysis was created from the BP measurement. Accordingly, we have four ordered groups of respondents: normal, prehypertension, stage 1 hypertension, and stage 2 hypertension. However, $<4 \%$ of adults were classified as being at stage 2 hypertension. For the purpose of regression modelling (more precisely to avoid problems with zero cell counts while estimating models), stage 1 and stage 2 groups were combined to create a stage $1 / 2$ category and defined as hypertension as defined earlier ( $\mathrm{SBP} \geq 140 \mathrm{~mm} \mathrm{Hg} / \mathrm{DBP} \geq 90 \mathrm{~mm} \mathrm{Hg}$ diastolic).

Altogether three multivariate models-one for males only, another for females only, and one for males and females combined-were estimated. The variable alcohol consumption was dropped from the multivariate model for females due to an extremely skewed distribution (only $2.1 \%$ of surveyed females were found to consume alcohol during the month preceding the survey). Data were analysed using a statistical software (Stata V.13).

\section{RESULTS}

\section{Sample characteristics}

Table 1 presents the sample characteristics of the study population, where $44 \%$ of the population was found to

\section{Table 1 Sample characteristics}

\section{Variables}

Total population

$\%$ of male respondents

$\%$ of female respondents

$\%$ of respondents with normal blood pressure

$\%$ of respondents with prehypertension

$\%$ of respondents with stage 1 hypertension

$\%$ of respondents with stage 2 hypertension

$\%$ of respondents belonging to 18-29 age group

$\%$ of respondents belonging to $30-44$ age group

$\%$ of respondents belonging to 45-59 age group

$\%$ of respondents belonging to 60 and above age group

Median age of the respondents (in years)

Religion and ethnicity (\%)

Hindu SC

Hindu ST

Hindu non-SC/ST

Non-Hindu

Educational attainment (\%)

Non-literate

Primary

Secondary

Higher

Current tobacco user (smoked or used any tobacco related products in last 7 days)

Alcohol user (at least one standard drink * in 30 days preceding the survey)

BMI $\left(\mathrm{kg} / \mathrm{m}^{2}\right)$

$<18.5$

$18.5-22.9$

23.0-24.9

$\geq 25.0$

Mean monthly per capita expenditure (in Indian rupees)
Total number or percentage

28,455

50.7

49.3

56.0

32.1

8.4

3.5

26.4

36.2

25.9

11.5

38

34.2

7.7

31.0

27.1

39.1

21.0

29.1

10.8

41.1

10.9

42.8

43.5

7.5

6.2

Rs. 980 (Rs. 175, Rs. 19, 825)

${ }^{*}$ Refers to $30 \mathrm{~mL}$ of spirits, $285 \mathrm{~mL}$ of beer or $120 \mathrm{~mL}$ of wine; () denotes range.

$\mathrm{BMI}$, body mass index; SC, scheduled caste; ST, scheduled tribe. 
be non-normotensive, consisting mainly of prehypertensives. The majority of the respondents $(36 \%)$ were in the age group 30-44 years. Over one-third of the selected population was non-literate. Employment in the primary and secondary sectors together constituted nearly half of the work force in the study site; however, mean monthly per capita expenditure was less than 1000 Indian rupees (about US\$16) with substantial variation.

\section{Bivariate analysis of the sex differences in prevalence of hypertension}

Table 2 represents sex differences in the prevalence of hypertension by background characteristics. More than half of the adult males and more than one-third of adult females were non-normotensives. Prehypertension was found to be substantially higher among males than females. The prevalence of hypertension significantly increased with age irrespective of sex, though disproportionately, particularly after 45 years of age. The prevalence of hypertension for females was lower than that for males at a younger age and then crossed over and exceeded that for males. While non-SC/ST Hindu respondents were more prone to prehypertension and hypertension, the non-Hindus were the least likely to be affected by hypertension. Household affluence was found to be positively related with non-normotension among both males and females. Current tobacco usage was significantly associated $\left(\chi^{2}\right.$ test $)$ with increased risk of hypertension irrespective of sex (males 14.1\%, females $16.7 \%$ ). Being overweight and obese was found to have a positive, significant relation $\left(\chi^{2}\right.$ test $)$ with hypertension for both sexes, but the prevalence was higher among males in this category.

\section{Multivariate analysis}

The ORs with 95\% CI estimated from the generalised ordered logit regression model, explaining the risk factors of hypertension, is presented in table 3. Sex was found to be a significant covariate, with females having a lower likelihood for non-normotension and hypertension (OR $0.50,95 \%$ CI 0.47 to 0.53 ; and OR $0.88,95 \%$ CI 0.80 to 0.96 , respectively). Of the total population, the likelihood of non-normotension and hypertension increased significantly as age increased, and the

Table 2 Prevalence of hypertension by background characteristics, stratified by sex ( $N=27589)$

\begin{tabular}{|c|c|c|c|c|c|c|}
\hline \multirow[b]{2}{*}{ Background characteristics } & \multicolumn{3}{|l|}{ Males } & \multicolumn{3}{|l|}{ Females } \\
\hline & Normal & Prehypertension & Hypertension & Normal & Prehypertension & Hypertension \\
\hline \multicolumn{7}{|l|}{ Age (years) ${ }^{\star \star \star}$} \\
\hline $15-24$ & 55.2 & 41.2 & 3.7 & 82.5 & 16.4 & 1.2 \\
\hline $25-34$ & 54.8 & 39.6 & 5.6 & 80.7 & 16.9 & 2.5 \\
\hline $35-44$ & 51.6 & 39.0 & 9.4 & 66.7 & 25.5 & 7.8 \\
\hline $45-60$ & 44.4 & 38.2 & 17.4 & 45.2 & 34.6 & 20.2 \\
\hline $60+$ & 29.0 & 37.3 & 33.8 & 25.1 & 35.5 & 39.4 \\
\hline \multicolumn{7}{|l|}{ Religion and ethnicity** } \\
\hline Hindu SC & 49.9 & 38.0 & 12.1 & 67.2 & 22.8 & 10.1 \\
\hline Hindu ST & 47.9 & 40.5 & 11.6 & 63.6 & 26.1 & 10.3 \\
\hline Hindu non-SC/ST & 44.2 & 40.6 & 15.2 & 56.7 & 29.7 & 13.6 \\
\hline Non-Hindu & 51.5 & 38.2 & 10.3 & 67.8 & 21.9 & 10.3 \\
\hline \multicolumn{7}{|l|}{ Expenditure class ${ }^{\star \star *}$} \\
\hline Poorest & 53.1 & 36.6 & 10.3 & 69.7 & 21.0 & 9.3 \\
\hline Poorer & 50.4 & 38.4 & 11.2 & 67.0 & 23.4 & 9.6 \\
\hline Middle & 49.1 & 39.3 & 11.5 & 65.5 & 24.0 & 10.6 \\
\hline Richer & 47.8 & 39.5 & 12.7 & 62.7 & 25.0 & 12.3 \\
\hline Richest & 41.2 & 41.9 & 17.0 & 53.7 & 31.5 & 14.9 \\
\hline \multicolumn{7}{|l|}{ Tobacco use $e^{\star \star \star}$} \\
\hline Non-user & 49.1 & 40.7 & 10.1 & 65.9 & 24.4 & 9.7 \\
\hline User & 48.0 & 38.0 & 14.1 & 56.2 & 27.1 & 16.7 \\
\hline \multicolumn{7}{|l|}{ Alcohol consumption** } \\
\hline Non-user & 48.9 & 38.8 & 12.3 & - & - & - \\
\hline User & 46.5 & 40.2 & 13.3 & - & - & - \\
\hline \multicolumn{7}{|l|}{ BMI $\left(\mathrm{kg} / \mathrm{m}^{2}\right)^{\star \star \star}$} \\
\hline$<18.5$ & 58.3 & 32.4 & 9.4 & 70.9 & 19.5 & 9.6 \\
\hline $18.5-22.9$ & 44.8 & 42.3 & 13.0 & 63.2 & 26.2 & 10.7 \\
\hline 23.0-24.9 & 26.7 & 52.4 & 20.9 & 49.9 & 35.2 & 15.0 \\
\hline$\geq 25.0$ & 23.5 & 51.8 & 24.7 & 43.8 & 36.7 & 19.4 \\
\hline Total & 48.4 & 39.1 & 12.5 & 63.8 & 24.9 & 11.3 \\
\hline
\end{tabular}

Significance levels from $\chi^{2}$ tests are identical for males and females $\left({ }^{* * *} p<0.001 ;{ }^{* *} p<0.01\right)$.

BMI, body mass index; SC, scheduled caste; ST, scheduled tribe.

- Information of alcohol consumption for females is not applicable. 
Table 3 Adjusted OR (with 95\% Cl) of generalised logit regression for males and females

\begin{tabular}{|c|c|c|c|c|c|c|}
\hline \multirow[b]{2}{*}{ Background characteristics } & \multicolumn{2}{|l|}{ Total } & \multicolumn{2}{|l|}{ Males } & \multicolumn{2}{|l|}{ Females } \\
\hline & Non-normotension† & Hypertension & Non-normotension† & Hypertension & Non-normotension† & Hypertension \\
\hline \multicolumn{7}{|l|}{ Sex (ref: male) } \\
\hline Female & $0.50(0.47 \text { to } 0.53)^{\star \star \star}$ & $0.88(0.80 \text { to } 0.96)^{\star \star \star}$ & & & & \\
\hline Age & $1.04(1.04 \text { to } 1.04)^{\star \star \star}$ & $1.06(1.06 \text { to } 1.06)^{\star \star \star}$ & $1.03(1.01 \text { to } 1.03)^{\star \star \star}$ & $1.04(1.03 \text { to } 1.05)^{\star \star \star}$ & $1.06(1.05 \text { to } 1.07)^{\star \star \star}$ & $1.08(1.07 \text { to } 1.09)^{\star \star \star}$ \\
\hline \multicolumn{7}{|l|}{ Education (ref: non-literate) } \\
\hline Up to primary & $1.04(0.96$ to 1.11$)$ & 0.98 (0.88 to 1.10$)$ & $1.11(1.01 \text { to } 1.23)^{\star \star}$ & 1.10 (0.95 to 1.28$)$ & 0.99 (0.89 to 1.10$)$ & $0.92(0.79$ to 1.08$)$ \\
\hline Up to secondary & $1.00(0.93$ to 1.08$)$ & 0.96 (0.86 to 1.07$)$ & $1.16(1.05 \text { to } 1.28)^{\star \star \star}$ & $1.04(0.90$ to 1.21$)$ & 0.97 (0.86 to 1.09$)$ & $1.03(0.86$ to 1.23$)$ \\
\hline >Secondary & $1.06(0.95$ to 1.18$)$ & 0.91 (0.78 to 1.07$)$ & $1.31(1.15 \text { to } 1.50)^{\star \star \star}$ & $1.00(0.83$ to 1.22$)$ & $0.66(0.54 \text { to } 0.82)^{\star \star \star}$ & 0.76 (0.52 to 1.10$)$ \\
\hline \multicolumn{7}{|c|}{ Religion and ethnicity (ref: Hindu non-SC/ST) } \\
\hline Hindu-SC & $0.96(0.89$ to 1.03$)$ & $1.03(0.92$ to 1.14$)$ & 1.07 (0.96 to 1.18$)$ & $1.04(0.90$ to 1.21$)$ & $0.84(0.76 \text { to } 0.94)^{\star \star \star}$ & 1.05 (0.90 to 1.23$)$ \\
\hline Hindu-ST & $1.05(0.93$ to 1.17$)$ & $0.98(0.82$ to 1.17$)$ & $1.10(0.94$ to 1.29$)$ & $0.98(0.77$ to 1.26$)$ & $0.99(0.83$ to 1.18$)$ & $1.07(0.82$ to 1.40$)$ \\
\hline Non-Hindu & $0.83(0.77$ to 0.89$) * * *$ & $\left(0.88(0.79 \text { to } 0.97)^{\star *}\right.$ & 0.95 (0.86 to 1.04$)$ & $0.77(0.67 \text { to } 0.89)^{\star * *}$ & $0.73(0.66 \text { to } 0.82)^{\star \star *}$ & $1.03(0.88$ to 1.20$)$ \\
\hline \multicolumn{7}{|c|}{ Economic status (ref: poorest) } \\
\hline Poorer & $1.09(1.01$ to 1.18$)$ ** & 0.99 (0.88 to 1.13$)$ & $1.11(1.00 \text { to } 1.24)^{*}$ & $0.98(0.83$ to 1.17$)$ & 1.05 (0.93 to 1.19$)$ & $1.01(0.83$ to 1.22$)$ \\
\hline Middle & $1.09(1.00 \text { to } 1.18)^{\star}$ & $1.05(0.93$ to 1.19$)$ & $1.11(0.99 \text { to } 1.23)^{\star}$ & $1.06(0.90$ to 1.26$)$ & $1.04(0.92$ to 1.17$)$ & $1.03(0.85$ to 1.24$)$ \\
\hline Richer & $1.08(1.00 \text { to } 1.18)^{*}$ & $1.10(0.97$ to 1.25$)$ & $1.09(0.97 \text { to } 1.21)^{\star}$ & 1.09 (0.91 to 1.29$)$ & 1.05 (0.93 to 1.20$)$ & $1.11(0.92$ to 1.34$)$ \\
\hline Richest & $1.18(1.08 \text { to } 1.29)^{\star \star \star}$ & $1.14(1.00 \text { to } 1.29)^{*}$ & $1.16(1.02 \text { to } 1.31)^{\star \star}$ & $1.21(1.01 \text { to } 1.45)^{\star \star}$ & $1.15(1.01 \text { to } 1.31)^{\star \star}$ & 1.04 (0.86 to 1.26$)$ \\
\hline \multicolumn{7}{|l|}{ Tobacco use (ref: non-user) } \\
\hline Current user & $0.91(0.86 \text { to } 0.97)^{\star \star \star}$ & 1.08 (0.99 to 1.18$)$ & $0.90(0.84 \text { to } 0.98)^{\star \star}$ & $1.16(1.03 \text { to } 1.30)^{\star \star}$ & 0.98 (0.89 to 1.08$)$ & 1.04 (0.91 to 1.19$)$ \\
\hline \multicolumn{7}{|l|}{ Alcohol (ref: non-user) } \\
\hline User & $1.15(1.05 \text { to } 1.26)^{\star \star *}$ & $1.19(1.04 \text { to } 1.36)^{\star *}$ & $1.24(1.12 \text { to } 1.38)^{\star \star *}$ & $1.16(0.99 \text { to } 1.35)^{*}$ & - & - \\
\hline \multicolumn{7}{|c|}{ 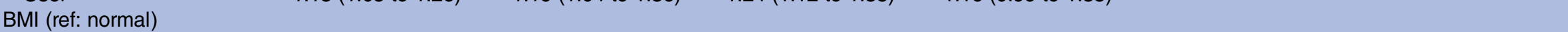 } \\
\hline Underweight & $0.59(0.56 \text { to } 0.62)^{\star \star \star}$ & $0.68(0.63 \text { to } 0.74)^{\star \star \star}$ & $0.57(0.53 \text { to } 0.61)^{\star \star \star}$ & $0.65(0.58 \text { to } 0.73)^{\star \star *}$ & $0.60(0.55 \text { to } 0.65)^{\star \star \star}$ & $0.69(0.61 \text { to } 0.79)^{\star \star \star}$ \\
\hline Overweight & $1.70(1.54 \text { to } 1.87)^{\star \star \star *}$ & $1.48(1.30 \text { to } 1.69)^{\star \star \star}$ & $2.00(1.71 \text { to } 2.33)^{\star \star \star}$ & $1.64(1.38 \text { to } 1.97)^{\star \star \star}$ & $1.54(1.34 \text { to } 1.76)^{\star \star \star}$ & $1.32(1.08 \text { to } 1.60)^{\star * *}$ \\
\hline Obese & $1.15(1.01 \text { to } 1.32)^{\star \star}$ & $1.25(1.06 \text { to } 1.47)^{\star \star \star}$ & $2.28(1.89 \text { to } 2.76)^{\star \star \star}$ & $1.93(1.58 \text { to } 2.37)^{\star \star \star}$ & $1.87(1.62 \text { to } 2.15)^{\star \star \star}$ & $1.81(1.50 \text { to } 2.18)^{\star \star \star}$ \\
\hline Pseudo $\mathrm{R}^{2}$ & 0.095 & & 0.062 & & 0.128 & \\
\hline Number of cases & 27589 & & 13994 & & 13595 & \\
\hline
\end{tabular}


direction of association was the same for male and female respondents.

Level of education was not found to be significantly associated with non-normotension and hypertension, whereas with increasing education level, nonnormotension was likely to be higher among males. While non-Hindus were significantly less likely to be affected by non-normotension and hypertension compared to Hindu non-SC/ST respondents (OR 0.83, 95\% CI 0.77 to 0.89 ; and OR $0.88,95 \%$ CI 0.79 to 0.97 , respectively), the risks of non-normotension and hypertension did not differ significantly by social group affiliation among Hindus. Risk of non-normotension significantly increased with economic class (OR 1.09, 95\% CI 1.01 to 1.18 among poorer; OR 1.09 , 95\% CI 1.00 to 1.18 among middle; OR $1.08,95 \%$ CI 1.00 to 1.18 among richer; OR $1.18,95 \%$ CI 1.08 to 1.29 among richest). Furthermore, respondents belonging to the highest economic class were significantly more likely to be affected by hypertension compared to the poorest (OR 1.14, 95\% CI 1.00 to 1.29 ). The direction of association was similar when studied separately for males and females.

While tobacco use was negatively associated with nonnormotension (OR 0.91, 95\% CI 0.86 to 0.97 ), it did not significantly increase the risk of hypertension. Alcohol usage had positive and significant effects on nonnormotension and hypertension (OR 1.15, 95\% CI 1.05 to 1.26 ; and OR $1.19,95 \%$ CI 1.04 to 1.36 , respectively).

While being underweight significantly reduced the risk of non-normotension and hypertension (OR 0.59, $95 \%$ CI 0.56 to 0.62 ; and OR $0.68,95 \%$ CI 0.63 to 0.74 , respectively), overweight persons were significantly more likely to suffer from non-normotension and hypertension (OR 1.70, 95\% CI 1.54 to 1.87 ; and OR $1.48,95 \%$ CI 1.30 to 1.69 , respectively). Obese respondents were significantly more likely to be affected by nonnormotension as well as hypertension compared to respondents with normal BMI (OR 1.15, 95\% CI 1.01 to 1.32; and OR $1.25,95 \%$ CI 1.06 to 1.47 , respectively). Though analysed separately for males and females, the direction is the same.

\section{DISCUSSION}

Using data from a Health and Demographic Surveillance site of West Bengal, India, this study assesses the sex differences in hypertension. While past studies on sex differences in the prevalence of hypertension in India have been inconclusive, ${ }^{19-21}$ this study reveals a higher likelihood of hypertension among men compared to women. A large-scale study conducted in Haryana also observed that more men experienced hypertension than women. ${ }^{4}$ In confirmation of an earlier study conducted in rural areas of West Bengal, prehypertension was more common than hypertension among the respondents. ${ }^{22}$ Additionally, in line with the findings of other developed and developing societies, traditional risk factors such as age and BMI were found to be most strongly associated with non-normotension and hypertension, irrespective of sex even after controlling for other potential confounders. ${ }^{9}$ 22-26

The prevalence of hypertension for females in this study is lower than males at a younger age but exceeds males when older, which corroborates the literature indicating the role of oestrogen as a protective factor until menopause. ${ }^{8}$ Experimental and clinical data reveal that oestrogen exerts different cardiovascular effects, including vasorelaxation, sympatho-inhibition, prevention of vascular remodelling, and subsequently decreased aortic stiffness through activity on the endothelium and smooth muscle cells, ${ }^{27}$ which all act as a protective factor against hypertension. Oestrogen values fall abruptly in postmenopausal women, leading to hypertension. Arterial stiffness becomes more pronounced in postmenopausal women than men, contributing to BP enhancement. ${ }^{28}$

We hypothesised that observed sex differences in hypertension may be in part due to differences in risk factors, such as BMI, smoking, and physical activity. ${ }^{7} 29$ However, taking these factors into account had virtually no effect on the sex differences in hypertension. This suggests that the sex differences among young adults may be partly due to biological sex differences, but more research is needed to investigate other behavioural factors that may explain this early disparity.

Importantly, a strong effect of education on nonnormotension is evident in men even after adjustment for confounding factors, but not among women. This may be because with enhancement of educational attainment men are more likely to engage in high paid sedentary occupations, thus are more likely to be physically inactive and stressed, which could lead to hypertension. Educated women, however, are less likely to be engaged in such occupations due to less working opportunity in this rural area; instead they are more likely to be engaged in daily household chores, farming, and other physical activities.

Additionally, our study found that economic affluence, although associated with hypertension among males, showed no association among females even after controlling for potential confounders. It seems that other unmeasured factors related to sex differentials in socioeconomic status may come into play in explaining the occurrence of hypertension. In addition, longstanding stress linked to the larger social environment is an important contributor to hypertension risk, ${ }^{30}$ and the residential environment can also contribute to the development of hypertension. ${ }^{31}$ In the current study set up, commenting on the effect of the neighbourhood would be difficult as it is homogeneous throughout the study area.

Similarly some effect of socio-religious affiliation on non-normotension or hypertension was evident in both men and women, even after adjusting for other potential confounders associated with higher social class (ie, affluence, education and BMI). In an underdeveloped rural 
region in India, ethnicity provides some measure of socioeconomic status. ${ }^{9}$ In the study region the majority of people who belonged to the SC, ST, and minority communities are generally engaged in labour-intensive agriculture and related activities. Furthermore, diet composition could also vary in different socio-religious groups. However, we do not have data to support this speculation.

Although a number of studies have pointed to the cardiovascular system as being one of the major targets for the damaging effects of smoking and other forms of tobacco use, ${ }^{26}{ }^{32-36}$ some findings identified that tobacco use, particularly smoking among males, is inversely related to systolic $\mathrm{BP}^{37} 38$ In our study we found that although tobacco use was inversely related to prehypertension, tobacco use had a positive and significant effect on hypertension even after controlling for other confounders. According to Leone, ${ }^{39}$ vasoconstriction mediated by nicotine causes an acute but transient increase in systolic BP initially, then a decrease in BP as a consequence of depressant effects caused chronically by nicotine itself. Although smokeless tobacco use was high among surveyed women, we did not find any significant association between tobacco use among women and increased hypertension, even after controlling for other confounders, implying the existence of some unknown mechanisms. In confirmation of other studies, we found alcohol consumption among males had a positive and significant effect on hypertension. ${ }^{26}{ }^{39}$ Alcohol intake was virtually non-existent in surveyed women so it can be dismissed as a potential causal factor for hypertension among female respondents.

Men and women differ in these key risk factors in complex ways. Smoking prevalence is lower among women than men, whereas overweight and obesity tend to be lower among men than women. ${ }^{40} 41$ However, these risk factors cannot fully explain the sex differences in hypertension, suggesting possibly that either their effects nullify each other (higher rates of obesity in women and current smoking in men) or the sex differentials in these behaviours cannot adequately explain the differences in hypertension. This implies that there is a different pathway by which unknown behavioural and socio-cultural factors come into play.

The pathways and factors that yield the sex differences for hypertension in such communities clearly deserve further study. We urge public initiatives are undertaken to generate awareness about NCDs like hypertension, as our dataset reveals that $74 \%$ of respondents with stage 1 hypertension and $56 \%$ of those with stage 2 hypertension were not receiving antihypertensive medication. Health promotion programmes, awareness generation, and reorientation of primary health care could be the strategies for early detection of hypertension and its management. ${ }^{42}$

\section{Limitations of the study}

Some limitations of the present study must be acknowledged. First, the study is based on cross-sectional data, which ideally does not allow for determining temporal relationships between hypertension and its risk factors. Secondly, since information on the known risk factors of hypertension, such as salt consumption, family history of hypertension, and duration of diabetes, were not available in the dataset, we could not determine their effect on hypertension in the current population. Other unmeasured factors may include genetic, social, and sexspecific characteristics. It is unclear how these factors may have affected the odds ratios obtained in the present study. Therefore it is possible that our findings may not be applicable universally to a larger population, although they may be generalised within the HDSS area.

Contributors SG, SM, and $A B$ contributed equally at the different stages of preparation of this manuscript.

Funding Financial support was received from the Department of Health and Family Welfare, Government of West Bengal, India (Memo number: HF/O/ MERT/ 1464/HSL (MISC)-35/2008).

\section{Competing interests None declared.}

Ethics approval The study conducted was in accordance with the ethical standards of the responsible committee on human experimentation (institutional and national) and with the Helsinki Declaration of 1975 (in its most recently amended version). An independent Ethical Review Board appointed by the chairman of the Society for Health and Demographic Surveillance, Government of West Bengal approved the study. Informed consent from the participants was taken before the survey. The information was anonymised. Further information on the ethical committee may be obtained from the website http://www.shds.in

Provenance and peer review Not commissioned; externally peer reviewed.

Data sharing statement No additional data are available.

Open Access This is an Open Access article distributed in accordance with the Creative Commons Attribution Non Commercial (CC BY-NC 4.0) license, which permits others to distribute, remix, adapt, build upon this work noncommercially, and license their derivative works on different terms, provided the original work is properly cited and the use is non-commercial. See: http:// creativecommons.org/licenses/by-nc/4.0/

\section{REFERENCES}

1. Open Working Group Proposal for Sustainable Development Goals [Internet] (cited 18 September 2014). http://sustainabledevelopment. un.org/focussdgs.html

2. Kearney PM, Whelton M, Reynolds K, et al. Global burden of hypertension: analysis of worldwide data. Lancet 2005;365:217-23.

3. Ezzati M, Lopez AD, Rodgers A, et al. Comparative Risk Assessment Collaborating Group. Selected major risk factors and global and regional burden of disease. Lancet 2002;360:1347-60.

4. Government of India, Report of the Working Group on disease burden for 12th Five Year Plan. New Delhi: Planning Commission, 2011.

5. World Health Organization. Noncommunicable Diseases (NCD) Country Profiles, 2011. http://www.who.int/nmh/countries/ind_en.pdf

6. Anchala R, Kannuri NK, Pant $\mathrm{H}$, et al. Hypertension in India: a systematic review and meta-analysis of prevalence, awareness, and control of hypertension. J Hypertens 2014;32:1170-7.

7. Everett B, Zajacova A. Gender differences in hypertension and hypertension awareness among young adults. Biodemography Soc Biol 2015;61:1-17.

8. Doumas M, Papademetriou V, Faselis C, et al. Gender differences in hypertension: myths and reality. Curr Hyperten Rep 2013;15:321-30.

9. Thrift A, Evans AG, Kalyanram K, et al. Gender-specific effects of caste and salt on hypertension in poverty: a population-based study. J Hypertens 2011;29:443-50.

10. National Health Survey 2001-2002. Hanoi (VN): Ministry of Health, General Statistics Office of Vietnam, Medical Publishing House; 2003. 
11. $\mathrm{Ng} \mathrm{N}$. Risk factors of elevated blood pressure in Purworejo, Central Java province, Indonesia: a preliminary study. Umeå International School of Public Health, Umeå University; 2001 Umeå, Sweden Everett B, Zajacova A. Gender differences in hypertension and hypertension awareness among young adults. Biodemography Soc Biol 2015;61:1-17

12. Dong GH, Wang D, Liu MM, et al. Sex difference of the prevalence and risk factors associated with prehypertension among urban Chinese adults from 33 communities of China: the CHPSNE study. $J$ Hypertens 2012;30:485-91.

13. Ghosh S, Barik A, Majumder S, et al. Health \& Demographic Surveillance System Profile: Birbhum population project (Birbhum HDSS). Int J Epidemiol 2015;44:98-107.

14. Chobanian AV, Bakris GL, Black HR, et al. The seventh report of the Joint National Committee on prevention, detection, evaluation, and treatment of high blood pressure: the JNC 7 report. JAMA 2003;289:2560-71.

15. Gupta S, Agarwal BK, Sehajpal PK, et al. Prevalence and predictors of essential hypertension in the rural population of Haryana, India: an hospital based study. J Rural Trop Public Health 2011;10:29-34.

16. Bhardwaj S, Balgir PP, Goel RK. Prevalence and predictors of hypertension, at Sriganganagar city of Rajasthan India. Asian $J$ Biomed Pharm Sci 2014;04:6-10.

17. Tyagi R, Dhall M, Kapoor S. Bio-social predictors of hypertension among premenopausal and postmenopausal women. SAGE Open 2015;5:2158244015574227.

18. Minh HV, Byass P, Chuc NT, et al. Gender differences in prevalence and socioeconomic determinants of hypertension: findings from the WHO STEPs survey in a rural community of Vietnam. J Hum Hypertens 2006;20:109-15.

19. Gupta R. Trends in hypertension epidemiology in India. J Hum Hypertens 2004;18:73-8.

20. Das SK, Sanyal K, Basu A. Study of urban community survey in India: growing trend of high prevalence of hypertension in a developing country. Int J Med Sci 2005;2:70-8.

21. Deshmukh PR, Gupta SS, Dongre AR, et al. Relationship of anthropometric indicators with blood pressure levels in rural Wardha. Indian J Med Res 2006;123:657-64.

22. Dutta A, Ray MR. Prevalence of hypertension and pre-hypertension in rural women: a report from the villages of West Bengal, a state in the eastern part of India. Aust J Rural Health 2012;20:219-25.

23. Brown CD, Higgins M, Donato KA, et al. Body mass index and the prevalence of hypertension and dyslipidaemia. Obes Res 2000;8:605-19.

24. Gus M, Fuch SC, Moreira LB, et al. Association between different measurements of obesity and the incidence of hypertension. Am $J$ Hypertens 2004;17:50-3.

25. Aekplakorn W, Kosulwat V, Suriyawongpaisal P. Obesity indices and cardiovascular risk factors in Thai adults. Int $J$ Obes (Lond) 2006;30:1782-90.
26. Satish T, Kannan S, Sarma PS, et al. Incidence of hypertension and its risk factors in rural Kerala, India: a community-based cohort study. Public Health 2012;126:25-32.

27. Orshal JM, Khalil RA. Gender, sex hormones, and vascular tone. Am J Physiol Regul Integr Comp Physiol 2004;286:R233-249.

28. Rossi $P$, Frances $Y$, Kingwell BA, et al. Gender differences in artery wall biomechanical properties throughout life. J Hypertens 2011;29:1023-33.

29. Reckelhoff JF. Gender differences in the regulation of blood pressure. Hypertension 2001;37:1199-208.

30. Pickering T. Cardiovascular pathways: socioeconomic status and stress effects on hypertension and cardiovascular function. Ann N Y Acad Sci 1999;896:262-77.

31. Diez Roux AV. Residential environments and cardiovascular risk J Urban Health 2003;80:569-89.

32. Leone A. Relationship between cigarette smoking and other coronary risk factors in atherosclerosis: risk of cardiovascular disease and preventive measures. Curr Pharm Des 2003;9:2417-23.

33. Leone A. Biochemical markers of cardiovascular damage from tobacco smoke. Curr Pharm Des 2005;11:2199-208.

34. Leone A, Landini L Jr, Biadi O, et al. Smoking and cardiovascular system: cellular features of the damage. Curr Pharm Des 2008;14: 1771-7.

35. Halimi JM, Giraudeu B, Vol S, et al. The risk of hypertension in men: direct and indirect effects of chronic smoking. J Hypertens 2002;20:187-93.

36. Niskanen L, Laaksonen DE, Nyssonen K, et al. Inflammation, abdominal obesity, and smoking as predictors of hypertension. Hypertension 2001;44:859-65.

37. Hughes K, Leong WP, Sothy SP, et al. Relationships between cigarette smoking, blood pressure and serum lipids in the Singapore general population. Int J Epidemiol 1993;22: 637-43.

38. Leone A, Lopez M, Picerno G. Role of smoking in coronary heart disease: hypothesis on the possible mechanism of myocardial damage. Minerva Cardioangiol 1984;32:435-9.

39. Leone A. Does smoking act as a friend or enemy of blood pressure? Let's release Pandora's box. Cardiol Res Pract 2011;2011:264894.

40. Haskell WL, Lee IM, Pate RR, et al. Physical activity and public health: updated recommendation for adults from the American College of Sports Medicine and the American Heart Association. Med Sci Sports Exerc 2007;39:1423-34.

41. National Center for Health Statistics (NCHS). Health United States. Washington DC, U.S. Government Printing Office, 2012.

42. Kaur P, Rao SR, Radhakrishnan E, et al. Prevalence, awareness, treatment, control and risk factors for hypertension in a rural population in South India. Int J Public Health 2012;57: 87-94. 